\title{
Coral responses to macroalgal reduction and fisheries closure on Caribbean patch reefs
}

\author{
T. R. McClanahan ${ }^{1, *}$, B. E. Huntington ${ }^{2}$, B. $\operatorname{Cokos}^{1}$ \\ ${ }^{1}$ Wildlife Conservation Society, Marine Programs, Bronx, New York 10460, USA \\ ${ }^{2}$ Rosenstiel School of Marine and Atmospheric Science, University of Miami, 4600 Rickenbacker Causeway, Miami, \\ Florida 33149, USA
}

\begin{abstract}
To determine the effects of algal reduction and fisheries closure, a crossed experimental design was undertaken over a $516 \mathrm{~d}$ period on the remote patch reefs of Glover's Reef Atoll, Belize. We investigated (1) the effects on health, growth, and survivorship of 2 transplanted coral species, Porites asteroides and Siderastrea siderea, and (2) the changes in the benthic and fish communities. Algal reduction ( $98 \%$ reduction by physical removal kept low by monthly removal) increased the abundance of all fish and slightly elevated herbivore bite rates. $P$. asteroides showed a temporal response to environmental conditions opposite of predictions, with higher bleaching and mortality in the unfished reefs cleared of algae. This may be due to reduced water flow at these sites as the growth rate of $P$. asteroides was positively related to water flow $\left(\mathrm{R}^{2}=0.35, \mathrm{p}=0.04\right)$. S. siderea growth showed no relationship with water flow and bleached slightly more in the control reefs. Nevertheless, there were no patterns in mortality, and growth rates were twice as high in the fished than unfished reefs for this species. This reef-scale study contrasts with results of small-scale experiments that found rapid, indirect coral mortality from erect algae. Rather, our results suggest that environmental conditions, notably reef location in relation to water flow, can be a considerably stronger factor influencing coral health than erect algae.
\end{abstract}

KEY WORDS: Marine reserve - Fishing effects - Coral growth • Algal-coral interactions · Bleaching $\cdot$ Management $\cdot$ Phase shifts Resale or republication not permitted without written consent of the publisher

\section{INTRODUCTION}

Understanding and promoting the factors that influence the recovery of corals is of considerable concern to Caribbean people dependent on reef resources, and reef managers tasked with conserving these resources. Reef ecosystems in the Caribbean are experiencing multiple human and natural disturbances that have caused major basin-wide changes in their ecology. Many Caribbean reefs have lost $90 \%$ of their hard coral cover since the 1970s and are now dominated by various algae associated with reductions in calcium carbonate deposition and reef growth (Gardner et al. 2003, Alvarez-Filip et al. 2009, Schutte et al. 2010). If this process continues, natural bioerosion rates will exceed the growth processes of calcium carbonate and cause reefs to decay (AlvarezFilip et al. 2009). As reefs decay, their ecological services including habitat for fish and fisheries productivity will decline (Paddack et al. 2009).

Losses of coral have been attributed to a series of diseases that killed the key foundation coral taxa, Acropora in 1981, and a key herbivore, Diadema antillarum in 1983 (Hughes 1994, Lessios 1988). Bleaching events and smaller-scale coral diseases since that period have either caused further declines or slowed the recovery of corals (Aronson \& Precht 2001). Poor water quality may have exacerbated these impacts or further reduced the recovery potential of Caribbean reefs (Kuntz et al. 2005). Short-term 
experimental evidence suggests that algae, in general, may cause the bleaching and mortality of corals indirectly (Kline et al. 2006, Nugues \& Bak 2006, Smith et al. 2006) or directly through contact (River \& Edmunds 2001, Nugues \& Bak 2006, Box \& Mumby 2007). Some specific algae contain allelopathic chemicals that can directly poison corals under experimental conditions (Rasher \& Hay 2010). Studies have also found negative effects of algae on coral reproduction (Foster et al. 2008) and recruitment (Box \& Mumby 2007, Diaz-Pulido et al. 2010, Kuffner et al. 2006) or direct competition (Jompa \& McCook 2002, 2003). Consequently, once algae are established, it may be difficult for corals to grow, complete their life cycle, and recover if patterns observed in these experiments are good analogues for natural field conditions.

Algae on Caribbean reefs have been remarkably persistent and possibly a good example of ecological hysteresis where recovery of corals is difficult once algae are established (Hughes et al. 2010). Experimental efforts to reduce algae in order to promote coral recovery found that algae return quickly, within $6 \mathrm{mo}$, and this is not sufficient time to facilitate coral recovery (McClanahan et al. 2001). There is some evidence that the recovery of herbivorous sea urchins and fishes facilitate coral recovery, but these changes have often been small or on a small spatial scale (Carpenter \& Edmunds 2006, Mumby et al. 2006, Maciá et al. 2007, Idjadi et al. 2010). Fisheries closures have been promoted as a way to increase herbivorous fish abundances, creating high grazing conditions required of corals. Nevertheless, reserve responses have been variable and possibly only effective in old closures with low initial levels of algae (Mumby \& Harborne 2010, Selig \& Bruno 2010, McClanahan \& Karnauskas 2011, McClanahan et al. in press). Consequently, knowledge of these coral reef ecological dynamics is not simple and there is much to learn in terms of the factors that influence coral-algal interactions and how to manage Caribbean reefs for the resilience and recovery of corals (McCook et al. 2001, Hughes et al. 2010).

The experiment described here is an attempt to evaluate 2 potential management strategies: (1) removal of algae and (2) fisheries closure on the health, growth, and survivorship of corals. This experiment was established on patch reefs in a remote field site where the field conditions and time scale used were more representative of current Caribbean reef conditions than previous small-scale manipulative experiments. Consequently, we undertook a crossed 2-factor design where 16 patch reefs located on the sand apron of Glover's Reef Atoll and patch reefs divided equally between a young fisheries closure ( 8 yr) and non-closure and where half of the reefs had their algae removed monthly over a $590 \mathrm{~d}$ period. We predicted higher coral mortality and decreased coral health and growth on patch reefs exposed to high levels of algae and those not protected from fishing.

\section{MATERIALS AND METHODS}

\section{Study sites and experimental design}

Glover's Reef Atoll is a coral-rimmed atoll $32 \mathrm{~km}$ long and $12 \mathrm{~km}$ wide located $\sim 45 \mathrm{~km}$ off the coast of mainland Belize (Fig. 1). There are nearly 850 patch reefs in this atoll's lagoon, and most of them have lost hard coral cover and become dominated by various erect algae since baseline measurements in the early 1970s (McClanahan \& Muthiga 1998). Brown algae in the genera Turbinaria, Sargassum, Lobophora, and Padina were the dominant algae and less abundant red and green genera can be found on most reef patches (McClanahan et al. 2001, McClanahan \& Karnauskas 2011). In 1993 the atoll was declared a marine reserve, subdivided into 3 management zones, and has been managed by the Belize Fisheries Department. The research was undertaken in the conservation zone (CZ) where fishing is prohibited and general use zone (GUZ) where spearguns are the dominant gear in use and the largest proportion of the catch is parrotfish followed by a variety of common carnivores, including snappers, jacks, groupers, angelfish, and barracuda (McClanahan et al. in press).

The study was undertaken on 16 shallow $(<2 \mathrm{~m}$ deep), small, and generally round-shaped patches $\left(<100 \mathrm{~m}^{2}\right)$ located on the sand apron of the windward side of the atoll (Fig. 1). The size of patch reefs was estimated from maximum and minimum diameter measurements, and the surface areas were calculated for placing fish abundance on a per area basis. The distance between the patch reefs in and out of the $\mathrm{CZ}$ was $\sim 5 \mathrm{~km}$. The windward side of the atoll is expected to have the cleanest water, due to prevailing water flow patterns across the atoll lagoon, but also not exposed to waves and storm surge. Additionally, seagrass and algae do not colonize the sand apron, and therefore influences from the surrounding biota are expected to be minimal. Consequently, these patch reefs were chosen to have the fewest external influences and disturbances while having what are expected to be good environmental conditions for coral health. 


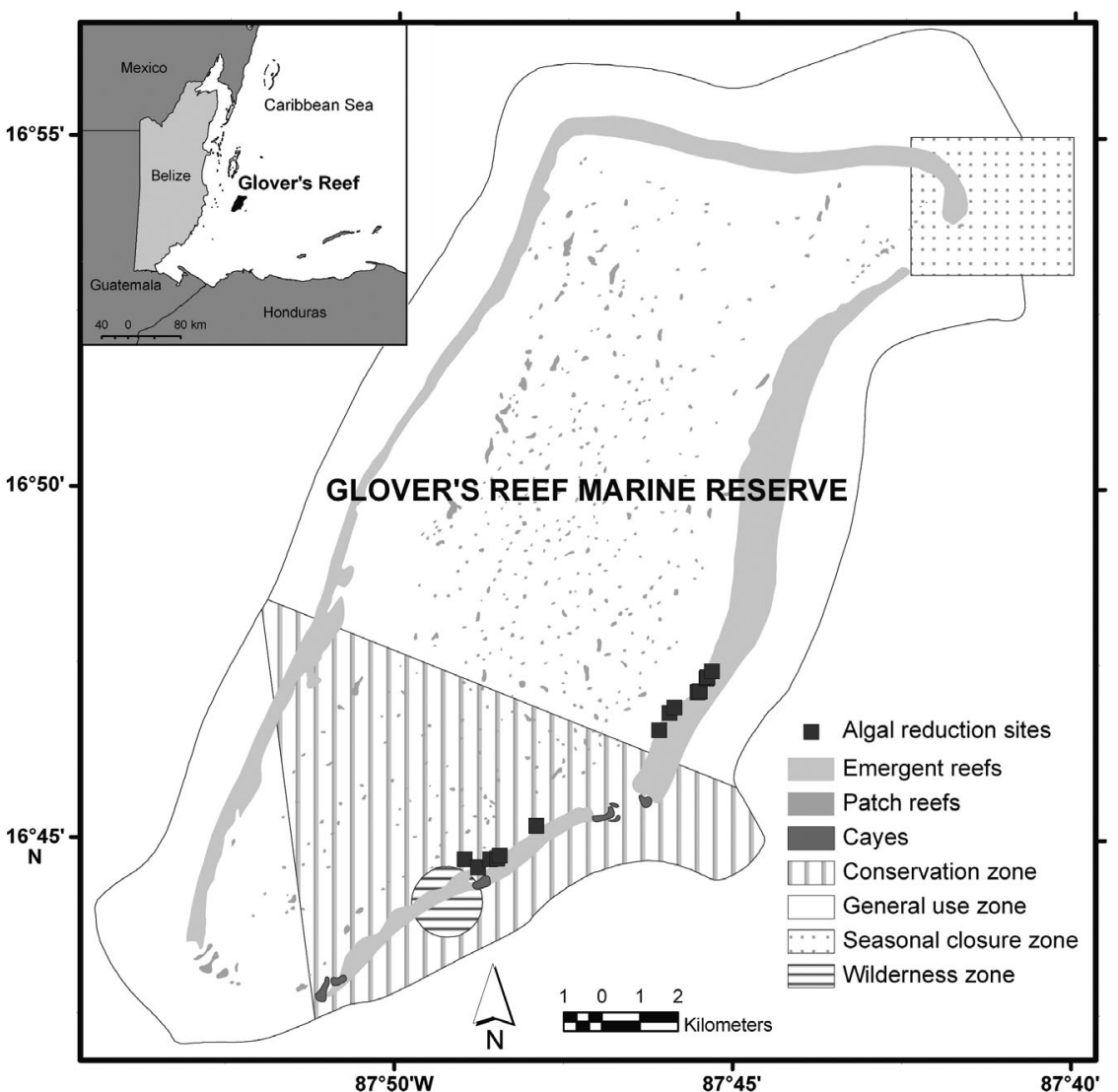

Fig. 1. Glover's Atoll, Belize, and location of experimental patch reefs on the sand apron of the conservation and general use zones

and this value was further reduced by the monthly removals. The algae that remained were largely holdfasts and algae that were not easily removed with these tools. Following this initial reduction, the 8 experimental patches were cleared of all re-growth using wire brushes and metal scrapers every month for a year (January-December 2003). Care was taken not to interfere with experimental coral transplants or any existing corals or coral recruits on the patch reefs.

To facilitate evaluating treatment effects on corals, 6 corals of similar size and initial condition were attached, or 'planted', with masonry cement on all 16 patches shortly after the algal reduction and field measurements. Collections of 96 fist-size corals from 2 taxa, Siderastrea siderea and Porites asteroides, were made from the adjacent back reef area with minimal erect algae. These species were chosen because they shared similar hemispherical shapes that would allow for easy measurements. Additionally, S. siderea was more likely to represent a stress-resistant (Muthiga \& Szmant 1987) and P. aster-

In January 2003, 16 of these patch reefs were selected based on having similar sizes ( 25 to $\left.50 \mathrm{~m}^{2}\right)$ such that half were in and out of the CZ. After initial measurements of benthic cover and fish abundance, half were haphazardly chosen for the experimental treatment of algal reduction, such that both the CZ and GUZ had 4 unmanipulated controls and 4 experimental patches. Field measurements were repeated on the experimental patch reefs 1 or $2 \mathrm{~d}$ after the algal reductions.

To perform the initial algal reduction, hedge clippers were used to clear the large fronds, and wire brushes with metal scrapers and wire brushes were used to remove smaller algae and, where possible, the holdfasts. Extreme care was taken to minimize the damage to surrounding corals and other benthic invertebrates. Approximately 30 person hours (5 individuals $\times 6 \mathrm{~h}$ in the water) were necessary for the initial algal reduction on each patch reef. The experimental patches averaged $4.2 \mathrm{~kg} \mathrm{~m}^{-2}$ of algal wet wt prior to cleaning, and after the reduction the mean wet wt per patch was reduced to $0.088 \mathrm{~kg} \mathrm{~m}^{-2}$. This is equivalent of $\sim 1$ to 2 tons of algae removed per patch, oides a faster-growing and opportunistic life history (Lirman et al. 2003). Collection locations were just windward of the experimental patch reefs but on the leeward side of the reef rim in areas of good water flow. Colonies were removed from the bottom with a chisel, placed in buckets, and transported $\sim 1$ to $3 \mathrm{~km}$ to the patch reefs. One sample of each species was fastened to the reef with masonry cement on the windward, middle, and leeward side of the patch reefs. These transplanted corals were checked $2 \mathrm{~d}$ later to determine if they had survived and if they were securely attached to the bottom. Transplant mortality or loss was very low, but any coral that had either come loose or died immediately following transplantation was replaced, rechecked 2 d later, and found to be secure and alive. After this transplantation period, all 96 corals were measured for initial size and assessed through time for changes in survival, health, and growth. Although algae were initially cleared in a small area before placing the masonry cement and for the planting process, erect algae growing alongside or over a planted coral were not removed in the control patches. Following these 
baseline assessments, sampling of the benthos and fish was done on either a monthly or quarterly basis, depending on the type of measurement.

\section{Monthly field sampling}

Seawater analyses. Seawater samples were collected in plastic and acid-rinsed Nalgene bottles from the experimental patches monthly for assessments of inorganic nitrogen, phosphorous, and suspended solids concentrations. The concentration of nitrates, nitrites, and ammonia were determined separately and the values added to determine total nitrogen. From each patch, a single $500 \mathrm{ml}$ sample was taken from the leeward edge $\sim 10$ to $20 \mathrm{~cm}$ from the bottom. Although only $15 \mathrm{ml}$ of each sample was used for any given test, large samples were taken from the patches to eliminate the risk of analyzing contaminated water. Samples were analyzed immediately using the Middle Key spectrophotometer (Hach Company model DR/2500; 2.5 cm cell length). Nitrates were analyzed using the cadmium reduction and phosphorus by the ascorbic acid methods. This method has a detection limit of $0.2 \mathrm{mg} \mathrm{l}^{-1}$ for nitrate, $0.002 \mathrm{mg} \mathrm{l}^{-1}$ for nitrite and a $0.02 \mathrm{mg} \mathrm{l}^{-1}$ limit for phosphorous. Water was sampled for the control patches on a quarterly basis as these patches were assumed to remain relatively stable.

Algal scrapings. To estimate algal biomass, a haphazardly tossed $25 \times 25 \mathrm{~cm}$ thin-wire quadrat was thrown on each patch, and all erect algae were scraped with a chisel. To reduce variability and need for replication, if the quadrat landed in a unrepresentative place (i.e. sand) or close to a planted coral, then it was thrown again until landed in a place that was hard bottom or more typical of the entire patch. All scraped algae other than benthic turf and encrusting coralline algae were collected in a plastic bag and taken back to the station's laboratory for weighing with a triple-beam balance (0.1 g accuracy). Due to noted differential water absorption and desiccation rates of various genera, all samples were left to dry for $\sim 4 \mathrm{~h}$ before weighing. Scrapings were taken once before the monthly cleaning and again afterwards selecting spots as described earlier in this paragraph, but insuring the same location was not sampled twice. By taking pre- and post-scrubbing samples, we were able to determine the monthly algal growth rates at each patch.

Coral health and mortality assessment. Visual evaluations were made to assess the health of the planted corals. Observations were divided into 3 cat- egories based on the initial, healthy coloration of the coral. Corals with no signs of lost coloration were recorded as 'healthy', corals with lost coloration were recorded as 'paling', and corals with white tissue exposed were recorded as 'bleached'. Corals that died during this period were also recorded, and the \% of corals in each category were calculated monthly.

Fish population counts. Monthly total counts of all the fish were made to species level on each patch by visual assessment. Species were counted by discrete group method based on their taxonomy, position in the reef or water column, and behavior. Groups were counted in a specific order, for example, snappers (Lutjanidae), which were wary of the observer, were counted first while territorial damselfishes (Pomacentridae) were counted last. The investigator approached and circumscribed the patches slowly so as not to scare away fish. One group was sampled during each pass around the outer edge of the reef. Fish $<3 \mathrm{~cm}$ were not counted. A final pass across the patch reef was made to insure that fishes in the center or hidden from view were counted. The count procedure lasted 30 to 45 min and included an average of $\sim 25$ different species. Surgeonfish and parrotfish were pooled together for some statistical analyses and referred to as herbivorous fish, although detritus is a part of their diet. Fish densities per patch reef were converted to a per area basis, based on estimates of the surface area of each patch reef, prior to statistical comparisons.

\section{Quarterly field sampling}

Additional measurements were made on both the experimental and control patches $5 \times$ over the $590 \mathrm{~d}$ period.

Water flow. Calcium-sulphate 'clods' were used to measure current strength on each patch reef and reef location on calm days (wind < 15 knots) (Doty 1971, McClanahan \& Karnauskas 2011). The dissolution rate of clods can be used to approximately measure integrated water motion and converted to currentstrength estimates from weight-loss experiments in controlled flumes (Thompson \& Glenn 1994). Clods were made from plaster of Paris poured into ice cube trays, allowed to set and dry in the sun, sanded to a uniform shape, and glued with waterproof epoxy to plastic $10 \times 10 \mathrm{~cm}$ squares bases. Holes were drilled in the corners of the plastic squares so they could be attached to the reef using thin copper wire in the 3 reef locations. Time of deployment and original weight of the clod card were recorded, and clods were retrieved $48 \mathrm{~h}$ later. Clods were sun-dried for $2 \mathrm{~d}$ and then reweighed. The loss in clod weight 
$\left(\mathrm{g} \mathrm{d}^{-1}\right)$ was converted to flow rate $\left(\mathrm{cm} \mathrm{s}^{-1}\right)$ using $([x-0.932] / 2.357)$, where $x$ is clod loss per day (Anzai 2001).

Benthic cover and algal biomass. Benthic cover on each patch was assessed by three $10 \mathrm{~m}$ line-intercept transects per patch reef (McClanahan 1999). Transects were haphazardly draped over each patch so that they followed the contours of 3 zones (windward, middle, and leeward). All substrate cover $>3 \mathrm{~cm}$ under the line was measured and recorded to species for stony corals and to the genus for fleshy and calcareous algae. Other taxa were also pooled into gross functional groups, including encrusting coralline algae, branching coralline algae, algal turf, sponge, and soft corals.

Herbivory assays. Assays of the seagrass Thalassia testudinum were used to estimate herbivory (Hay 1981, McClanahan et al. 1994). Seagrass blades were collected from the seagrass beds in the Wilderness Zone, inspected to avoid using pre-bitten or epiphyte covered samples, and cut to a standard length of $10 \mathrm{~cm}$. Clippings were held in weighted clothespins attached at $\sim 2 \mathrm{~m}$ intervals along a thin nylon line draped around the shoulder of each patch such that it was never resting on sand or lying across gaps. Assays were left for $24 \mathrm{~h}$ before recovering and examining for bites. The observer recorded whether or not the samples had been bitten, the amount bitten (to the closest $0.5 \mathrm{~cm}$ ) and, based on bite scar characteristics, which herbivores were responsible for the bites: finfish or sea urchins (Hay et al. 1983, McClanahan et al. 1994). The mean number of bites by fish and urchins, and the percentage of seagrass lost to grazing were calculated. This herbivory assay method is biased towards macroalgal feeding species and underestimates herbivory by some groups such as scraping and excavating parrotfish and sea urchins, and does not measure herbivory by some sucking and scraping species such as most grazing surgeonfish (McClanahan et al. 1994). The combination of herbivores counts and the assay was expected to reflect herbivory differences between treatments.

Coral size measurements. Planted coral sizes were measured with Vernier caliper to the nearest $\mathrm{mm}$, where each coral colony's length and width was measured using the longest and shortest edges of the coral as the standard for length and width measurements. These 2 measurements were used to determine the coral's approximate area (oval assumption $\mathrm{A}=\mathrm{L} \times \mathrm{W} \times 0.8$ ) and change over the 4 mo period. Percent change in colony size $\left(\mathrm{cm}^{-2}\right)$ from initials was calculated over the $590 \mathrm{~d}$ interval (13 January 2003 to 5 August 2004) for transplanted Siderastrea siderea and Porites asteroides colonies. The small number of corals that exhibited $100 \%$ mortality was excluded from coral growth analysis.

\section{Data analyses}

Initial effects of the algal reduction on the benthic and fish community composition of experimental patch reefs were explored using 2-way fixed factor ANOVAs (Management $\times$ Time). The effects of the repeated reduction of algae over time were tested with 3-way fixed factor ANOVAs with 4 replicate patch reefs in each of the experimental treatments (algae reduction and fishing reduction) with Time as the third factor. A repeated measures ANOVA was not an appropriate statistical test as sampling was conducted on haphazardly placed rather than fixed transects or quadrats. This analysis was applied to the benthic cover, fish abundance, and herbivory data. Data were tested for normality and homogenous variances using the Shapiro-Wilks' and Cochran's tests, respectively. Square root and $\log _{10}(x+1)$ transformations were aplied to meet the assumption of normality and equal variance when necessary. For the analysis of fish abundance, all species with $<30$ individual total sightings throughout the entire sampling period were excluded from the analyses. Only the abundance of one species, Chromis viridis, differed significantly between treatments before the algal removal (Tukey's HSD post hoc analysis, $\mathrm{p}<0.05$ ).

Frequency of coral bleaching, paling, and mortality for Siderastrea siderea and Porites asteroides were compared across management zone and treatment using likelihood ratio chi-squared tests. Coral growth was calculated as \% change in colony size from initial (January 2003) to final (August 2004) sampling periods and analyzed using 3-factor ANOVAs (Management zone $\times$ Treatment $\times$ Patch reef location) by coral species. Regression analyses were performed to evaluate relationships between coral growth rates and water flow estimates. Regression analysis matched both absolute change and proportional change in colony size from initial measurements over the entire study period to mean water flow for a given patch reef location (leeward, middle, or windward) grouped by management zone and algal treatment (as these factors were significant in 3-factor ANOVA analysis of flow across all study reefs. This created 12 different 'levels' of water flow rates for the regression analysis ( 3 patch reef locations $\times 2$ management zones $\times 2$ algal treatments). Presented graphs are based on pooled data such that only those treatments effects 
that were statistically significant are shown. Statistical tests were undertaken using the JMP 8.0 software package.

\section{RESULTS}

\section{Initial treatment effects}

The initial physical removal of macroalgae resulted in significant differences in estimates of benthic cover of 3 substrate categories: an increase in turf algae and hard coral and a decrease in erect fleshy algae (2-way ANOVAs: Time $\times$ Zone). As anticipated, the cover of fleshy algae declined regardless of management zone from a (mean \pm SE) pre-treatment level of $63.4 \pm 3.7 \%$ to a post-treatment level of 14.0 $\pm 4.3 \%(F=36.01, \mathrm{p}<0.0001)$. A larger drop was observed when algal abundance was estimated by scraping by biomass from a (mean \pm SE) pre-treatment level of $4226 \pm 632 \mathrm{~g} \mathrm{~m}^{-2}$ to a post-treatment level of $88 \pm 32 \mathrm{~g} \mathrm{~m}^{-2}$ (2-way ANOVA, $F=47.11$, $\mathrm{p}<0.0001)$

Analysis of initial total fish density and herbivore density found that, while herbivore density did not vary significantly between management zones nor before or after the initial algal removal treatment, a significant fisheries closure effect was found for total fish density (2-way ANOVA, $F=6.72$, p = 0.02), in which the GUZ zone had greater total numbers of fish (mean $\pm \mathrm{SE}=3.02 \pm 0.35$ ind. $\mathrm{m}^{-2}$ ) than the $\mathrm{CZ}$ zone $\left(1.83 \pm 0.34\right.$ ind. $\mathrm{m}^{-2}$; Student's $t$-test, $\left.t=2.18\right)$.

\section{Changes over time}

Water quality and flow. Both total $\mathrm{N}$ and $\mathrm{P}$ varied significantly over time (3-way $\mathrm{ANOVA}_{\text {; }}$ total N: $F=$ 6.81, p = 0.003; total P: $F=30.18, \mathrm{p}<0.0001)$ but not by treatment or management zone. Additionally, no significant effects of Time, Treatment, or Zone were detected for suspended solids. Seawater flow was determined to be significant and $23 \%$ greater in the GUZ compared to the CZ (Table 1; 3-way ANOVA, Zone $\times$ Treatment $\times$ Transplant location, $F=29.06, \mathrm{p}<$ 0.0001). Control reefs exhibited $13 \%$ higher flow rates than algal removal reefs $(F=7.99, \mathrm{p}=0.005)$, and windward and middle transplant locations on individual reefs exhibited higher flow than the leeward edge of the reef $(F=4.41, \mathrm{p}=0.012)$. None of the interaction terms between Zone, Treatment, and Transplant location for the 3-factor ANOVA were significant.
Table 1. Seawater flow rates $\left(\mathrm{cm} \mathrm{s}^{-1}\right)$ pooled across all sampling intervals and ANOVA results. Means $( \pm$ SE) are shown for the significant factors of management zone, treatment, and reef location following 3-way ANOVA analysis $\left({ }^{*} \mathrm{p}<0.05\right.$, bold $)$

\begin{tabular}{|c|c|c|c|}
\hline Treatment & Location & Mean & SE \\
\hline \multicolumn{4}{|c|}{ Conservation zone (CZ) } \\
\hline \multirow[t]{3}{*}{ Control } & Leeward & 3.65 & 0.39 \\
\hline & Middle & 3.99 & 0.39 \\
\hline & Windward & 3.96 & 0.33 \\
\hline \multirow[t]{3}{*}{ Experiment } & Leeward & 2.74 & 0.34 \\
\hline & Middle & 3.48 & 0.27 \\
\hline & Windward & 3.90 & 0.42 \\
\hline \multicolumn{4}{|c|}{ General use zone (GUZ) } \\
\hline \multirow[t]{3}{*}{ Control } & Leeward & 4.69 & 0.24 \\
\hline & Middle & 5.12 & 0.37 \\
\hline & Windward & 5.27 & 0.33 \\
\hline \multirow[t]{3}{*}{ Experiment } & Leeward & 3.92 & 0.34 \\
\hline & Middle & 4.57 & 0.37 \\
\hline & Windward & 4.66 & 0.34 \\
\hline \multicolumn{2}{|l|}{ Factor } & $F$ & $\mathrm{p}$ \\
\hline \multicolumn{2}{|l|}{ Management } & 29.05 & $0.0001 *$ \\
\hline \multicolumn{2}{|l|}{ Treatment } & 7.99 & $0.005^{*}$ \\
\hline \multicolumn{2}{|c|}{$\begin{array}{l}\text { Management } \times \text { Treatment } \\
0.72\end{array}$} & & 0.13 \\
\hline \multicolumn{2}{|c|}{ Location } & 4.41 & $0.014^{*}$ \\
\hline \multicolumn{2}{|c|}{ Management $\times$ Location } & 0.01 & 0.99 \\
\hline \multicolumn{2}{|c|}{ Treatment $\times$ Location } & 0.52 & 0.59 \\
\hline \multicolumn{2}{|c|}{ Management $\times$ Treatment $\times$ Location } & 0.25 & 0.77 \\
\hline
\end{tabular}

Treatment effects over time. Benthic cover changed significantly from February 2003 to May 2004, based on 3-way ANOVA (Zone $\times$ Treatment $\times$ Time) analyses (Table 2). Benthic cover did not vary across management zone for any of the benthic substratum measures. However, 4 benthic substrates did show changes across time and treatment (Fig. 2). Unsurprisingly, fleshly algae were consistently greater on control patches than experimental patches across the sampling intervals. However, fleshy algae cover did increase over time, with greater increases on experimental than control patches. The opposite pattern was observed for turf and encrusting coralline algae, which showed consistently greater cover in experimental removal patches versus control patches over time. Coral cover, while greater on experimental patches, declined significantly over time, regardless of patch reef treatment.

Measuring change in patch reef substrate from algal biomass scrapings over time also revealed a significant treatment effect with greater algal bio- 
Table 2. ANOVA table of results showing p-values from algal removal treatment on benthic substrate (3-factor ANOVA: Management zone $\times$ Algal removal treatment $\times$ Time) and transformation used to improve normality for each benthic category. Initial (pre-treatment) data excluded as well as sampling from period 2 in which only treatment patch reefs were sampled. E-coralline: encrusting coralline algae; B-coralline: branching coralline algae; Calcareous: green calcareous algae; $\mathrm{ns}=$ not significant

\begin{tabular}{|c|c|c|c|c|c|c|c|c|}
\hline $\begin{array}{l}\text { Benthic } \\
\text { substrate }\end{array}$ & Zone & Treatment & Time & $\begin{array}{l}\text { Time } \times \\
\text { Zone }\end{array}$ & $\begin{array}{l}\text { Time } \times \\
\text { Treatment }\end{array}$ & $\begin{array}{l}\text { Zone } \times \\
\text { Treatment }\end{array}$ & $\begin{array}{c}\text { Time } \times \text { Zone } \times \\
\text { Treatment }\end{array}$ & $\begin{array}{c}\text { Transformations } \\
\text { applied }\end{array}$ \\
\hline Hard coral & ns & ns & 0.027 & ns & ns & ns & ns & None \\
\hline Algal turf & ns & $<0.0001$ & ns & ns & ns & ns & ns & Square root ${ }^{\mathrm{a}}$ \\
\hline Fleshy erect algae & ns & $<0.0001$ & 0.005 & 0.016 & ns & 0.009 & ns & None $^{\mathrm{a}}$ \\
\hline E-coralline & ns & $<0.0001$ & $<0.0001$ & 0.001 & ns & 0.005 & ns & Square root ${ }^{\mathrm{a}}$ \\
\hline B-coralline & ns & ns & ns & ns & ns & ns & ns & $\log (x+1)$ \\
\hline Sponge & ns & ns & $\mathrm{ns}$ & ns & ns & ns & ns & $\log$ \\
\hline Gorgonian & ns & ns & ns & ns & ns & ns & ns & $\log$ \\
\hline Calcareous & ns & ns & ns & ns & ns & 0.003 & 0.007 & $\log (x+1)$ \\
\hline
\end{tabular}

mass on control patches compared to experimental patches (3-way ANOVA, $F=2523.38$, p < 0.0001). In addition, the overall algal biomass was significantly greater on CZ versus GUZ patches $(F=15.88$, p < 0.0001 ) and showed significant temporal variation with the greatest biomass values during the summer months $(F=3.06, \mathrm{p}=0.001)$. When algal biomass was averaged across all time periods, control reefs from the CZ and GUZ showed similar levels of algal biomass. However, removal resulted in significantly less algal biomass on GUZ compared to CZ patch reefs (Tukey's HSD post hoc analysis, p < 0.05).

Numbers of fish and grazing. Time was the most frequently statistically significant factor in the fish data, significant for 7 of the 9 tests, suggesting a strong seasonal pattern or summer usage of the patch reefs by herbivores (Table 3, Fig. 3). Management was significant for 6 tests, and the algal removal was significant for 3 of the 9 tests. Three of the 4 larger herbivores were more abundant in the CZ, namely the blue tang, and the stoplight and redband parrotfish, whereas there were no differences in the small striped parrotfish and doctorfish between management zones. The doctorfish and damselfish had interactive Treatment $\times$ Management effects but in the opposite directions - damselfish abundance increased and doctorfish decreased in the $\mathrm{CZ}$ after the algal removal and vice versa for the GUZ. Total fish numbers increased in the removal reefs immediately after the removal, and this difference was maintained until the October-November sampling.

Fish grazing on the experimental Thalassia testudinum assays greatly exceeded urchin grazing in both control and experimental patches for both management zones regardless of the time interval (Table 3). Fish grazing, measured as numbers of bites $\min ^{-1}$, was low overall but significant and only slightly greater on experimental (mean $\pm \mathrm{SE}=3.41 \pm$ 0.45) compared to control patches (mean $\pm \mathrm{SE}=$ $2.72 \pm 0.47, \mathrm{p}<0.05)$ and probably driven by the low fish grazing on the GUZ control patches. Urchin grazing was considerably higher in the GUZ, $\sim 10 \times$ greater than in the CZ $(\mathrm{p}<0.033)$. Estimates of T. testudinum tissue loss were low $(<16 \%)$, and no statistical differences between treatments were found.

Coral health and growth. To assess coral health, the frequency of observed full mortality, paling, and bleaching of coral tissue by management zone and algal removal treatment were examined. For Porites asteroides, low but significantly higher rates of mortality and bleaching were found in the CZ than the GUZ (likelihood ratio of mortality, chi-squared 26.7, p < 0.05; bleaching, chi-squared 27.3, p = 0.04) (Fig. 4a,b). Additionally, higher rates of mortality occurred in the experimental algal removal than the controls reefs (chi-squared 28.3, p = 0.03). For Siderastrea siderea, mortality and paling did not show any patterns with Management and Treatment. However, greater bleaching was observed in control reefs versus experimental reefs (chi-squared 12.2, p = 0.03) (Fig. 4b).

Analyses of the coral growth indicated high variation, no algal reduction treatment effects, but significant management zone effects for both species (Table 4, Fig. 4c). Siderastrea siderea growth averaged a $12.8 \pm 3.5 \%$ (mean $\pm \mathrm{SE}$ ) increase in colony size within the $\mathrm{CZ}$, but growth was twice as high in the GUZ (mean \pm SE: $27.8 \pm 4.0 \%$ ). The difference in Porites asteroides growth across zones was even greater, though more variable. Inside the CZ, transplanted $P$. asteroides colonies averaged a $1.7 \pm 6.5 \%$ (mean $\pm \mathrm{SE}$ ) increase in colony size, compared to a $24.3 \pm 6.5 \%$ (mean $\pm \mathrm{SE}$ ) increase in the GUZ. 
a)

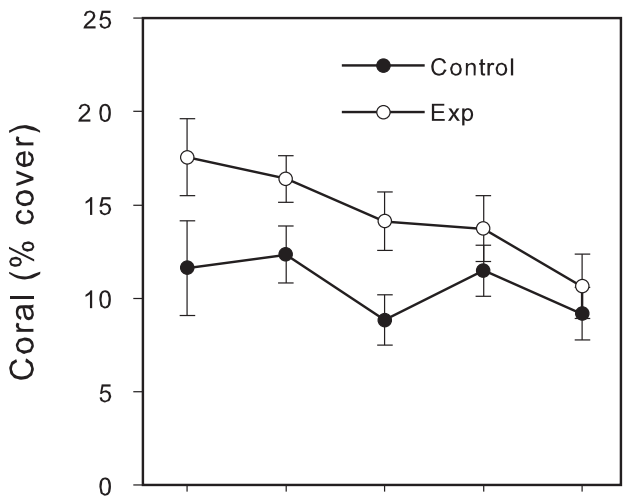

b)

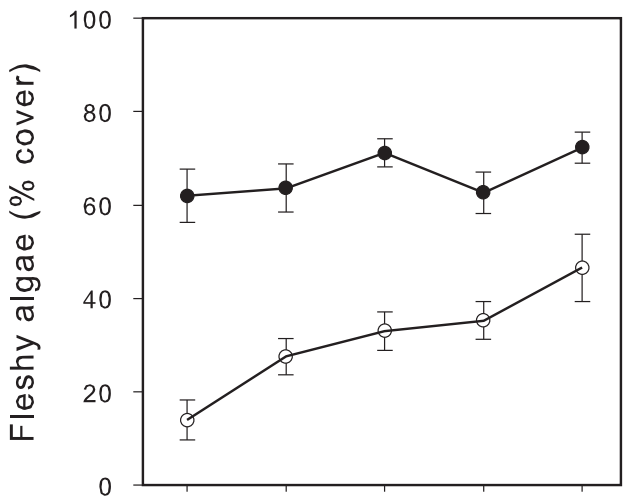

c)

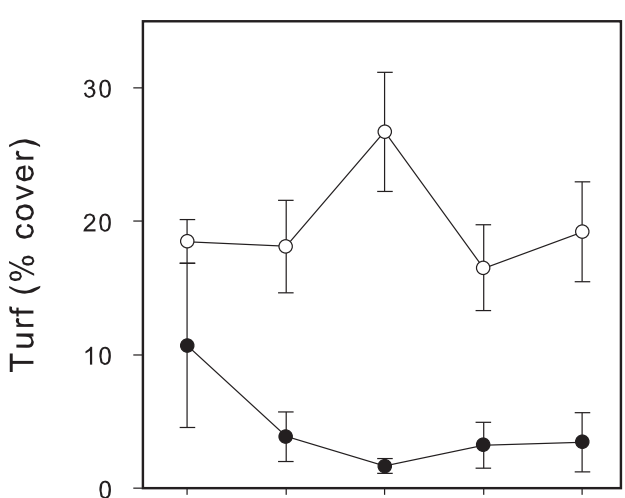

d)

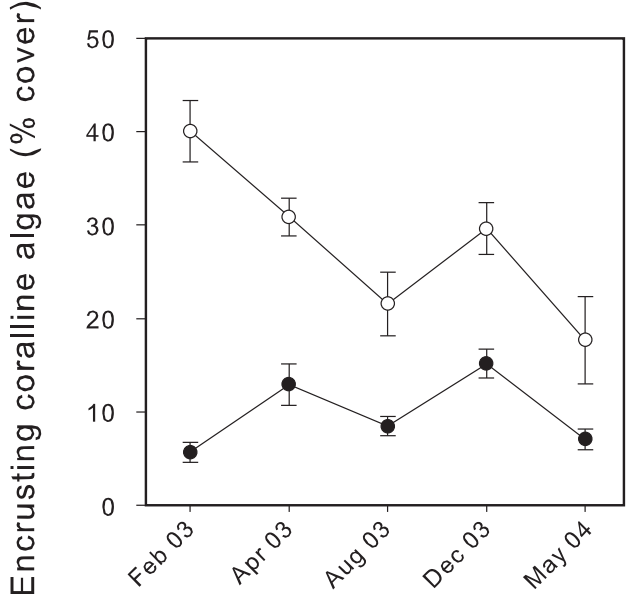

Date
Seawater flow rate was explored, using regression analysis, as a possible explanatory mechanism behind what could be driving rates of growth due to differences between management zones. Total coral growth as \% change from initial over the entire study period (January 2003-August 2004) was regressed against mean flow for a given transplant location (leeward, middle, or windward) grouped by zone and algal treatment (as these factors were significant in 3-factor ANOVA analysis of flow across all study reefs). A significant positive relationship between $\%$ change in coral growth and increasing flow was detected for Porites asteroides $\left(\mathrm{r}^{2}=0.35, \mathrm{p}=0.04\right.$, $\mathrm{n}=12$ ) but not for Siderastrea siderea.

\section{DISCUSSION}

Our results suggest that these 2 hard coral species can coexist with very abundant erect algae without a strong response in their condition for more than one year. Consequently, other factors such as recruitment limits, temperature anomalies, disease, and predation pressure could be more important than macroalgae in determining these species' health and survival (Vu et al. 2009, Venera-Ponton et al. 2011). Many of the small-scale experimental manipulations show immediate responses on the order of days to weeks (Smith et al. 2006, Liu et al. 2009), which we suggest are largely a result of experimental conditions that are atypical of field conditions. The reefscale field study reported here emulates the treatments of smaller laboratory experiments, but under conditions of natural water flow, nutrients, sunlight, spacing, and fish communities at much larger spatial and temporal scales. Consequently, the lack of agreement between our results and some previous investigation of algal-coral interaction suggests that experimental investigations exploring this complex algal-coral relationship should be conducted across longer temporal and large spatial scales that mimic natural systems. Macroalgae and corals have co-existed over long periods of evolutionary history, occupying the same habitat, and it is unexpected that algae would quickly kill corals at a distance under natural conditions.

Fig. 2. Change in benthic cover over time. Mean \%cover $( \pm \mathrm{SE})$ by treatment for each benthic substrate category exhibiting a significant change in cover over time or treatment is shown for experimental (O) and control patch reefs $(\bullet)$. No differences across management zones were detected (3-factor ANOVA), so results are pooled across zone 
Table 3. (A) Fish densities and (B) grazing rates per patch. Mean values, SE in parentheses. Fish densities (m ${ }^{-2}$ ) include the 6 most abundant herbivore species, damselfish, total fish, and total herbivorous fish pooled across post-treatment sampling intervals. Grazing rates were calculated as number of bites $\min ^{-1}$ for fish and urchins, and \% loss of experimental Thalassia testudinum assays. Significant factors and interactions from 3 -factor ANOVA (Zone $\times$ Treatment $\times$ Time) are shown at right: ${ }^{*} \mathrm{p}<0.05,{ }^{* *} \mathrm{p}<0.01$,

${ }^{* * *} \mathrm{p}<0.001$. Insignificant interactions are not shown

\begin{tabular}{|c|c|c|c|c|c|c|c|c|c|}
\hline \multirow[t]{2}{*}{ Fish species } & \multirow[t]{2}{*}{ Common name } & \multicolumn{2}{|c|}{ Conservation zone } & \multicolumn{2}{|c|}{ General use zone } & \multirow[t]{2}{*}{ Zone } & \multirow[t]{2}{*}{ Treatment } & \multirow{2}{*}{ Time } & \multirow{2}{*}{$\begin{array}{c}\text { Zone } \times \\
\text { Treatment }\end{array}$} \\
\hline & & Control & Expt & Control & Expt & & & & \\
\hline \multicolumn{10}{|l|}{ (A) Fish density } \\
\hline $\begin{array}{l}\text { Acanthurus } \\
\text { coeruleus }^{\mathrm{a}}\end{array}$ & Blue tang & $4.75(0.35)$ & $4.94(0.49)$ & $2.49(0.24)$ & $2.78(0.3)$ & $* * *$ & & $* * *$ & \\
\hline A. chirurgus ${ }^{\mathrm{a}}$ & Doctorfish & $3.56(0.48)$ & $3.65(0.52)$ & $3.71(0.43)$ & $2.88(0.36)$ & & & & \\
\hline A. bahianus ${ }^{\mathrm{a}}$ & Ocean surgeon & $2.15(0.3)$ & $1.14(0.32)$ & $2.12(0.27)$ & $2.50(0.59)$ & ** & $*$ & & * \\
\hline Scarus inserti ${ }^{\mathrm{a}}$ & Striped parrotfish & $45.40(2.98)$ & $45.24(3.67)$ & $39.94(3.07)$ & $37.88(3.35)$ & & * & $* * *$ & \\
\hline Sparisoma viride ${ }^{a}$ & Stoplight parrotfish & $8.58(0.76)$ & $9.02(0.75)$ & $6.64(0.71)$ & $5.44(0.49)$ & $* * *$ & & $* * *$ & \\
\hline $\begin{array}{l}\text { Sparisoma } \\
\text { aurofrenatum }^{\mathrm{a}}\end{array}$ & Redband parrotfish & $11.83(1.53)$ & $10.65(1.27)$ & $8.76(0.76)$ & $7.5(0.84)$ & $*$ & & ${ }^{* *}$ & \\
\hline Stegastes spp. & Damselfish & $38.92(2.06)$ & $48.06(3.08)$ & $29.75(1.88)$ & $25.02(0.94)$ & $* * *$ & & $* *$ & ${ }^{* *}$ \\
\hline Total fish & & $5.07(0.32)$ & $5.96(0.38)$ & $4.52(0.41)$ & $5.72(0.39)$ & $*$ & $* * *$ & $* * *$ & \\
\hline Total herbivores & & $1.46(0.08)$ & $1.49(0.08)$ & $1.26(0.09)$ & $1.52(0.1)$ & & & $* * *$ & \\
\hline \multicolumn{10}{|l|}{ (B) Grazing rates } \\
\hline Urchin bites & & $0.06(0.06)$ & $0.13(0.09)$ & $0.69(0.18)$ & $1.44(0.43)$ & $*$ & & & $*$ \\
\hline Fish bites & & $3.56(0.75)$ & $3.06(0.59)$ & $1.88(0.52)$ & $3.75(0.7)$ & & * & & \\
\hline T. testudinum loss & & $15.94(4.6)$ & $11.41(3.25)$ & $7.27(2.49)$ & $15.44(5.36)$ & & & & \\
\hline
\end{tabular}

\section{Experimental treatment effects}

Well-executed, small-scale mesocosm and aquarium experiments are often favored because environmental conditions can be controlled such that each variable can be analyzed and studied separately without confounding factors. Yet, laboratory and small-scale experiments create experimental arti-

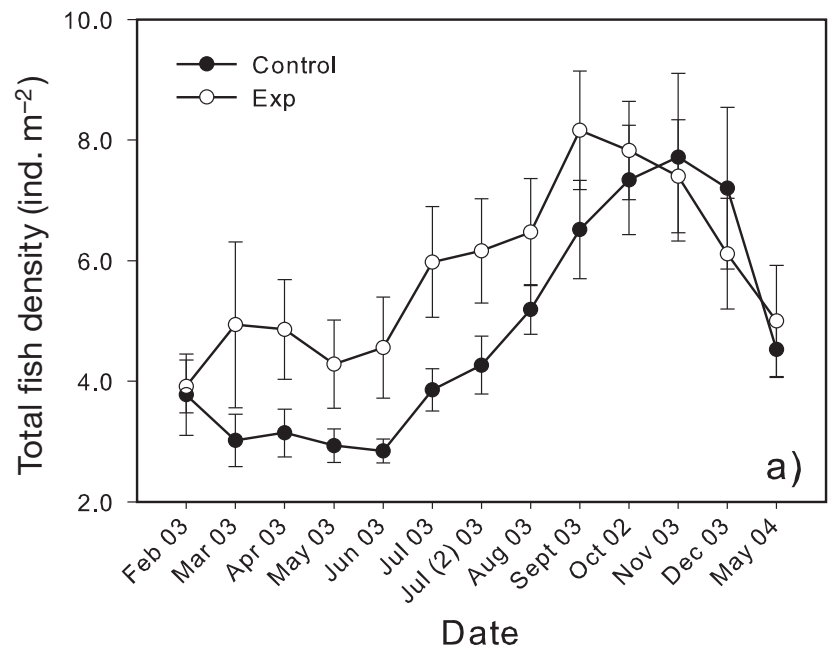

facts and environmental conditions that do not emulate conditions experienced by the species and, therefore, need to be interpreted and extrapolated to natural systems with caution. Similarly, experiments that restrict scale or multiple realistic interactions may overlook factors critical to the health and survival of corals (Venera-Ponton et al. 2011). Many algal-coral competitive experiments that have found negative

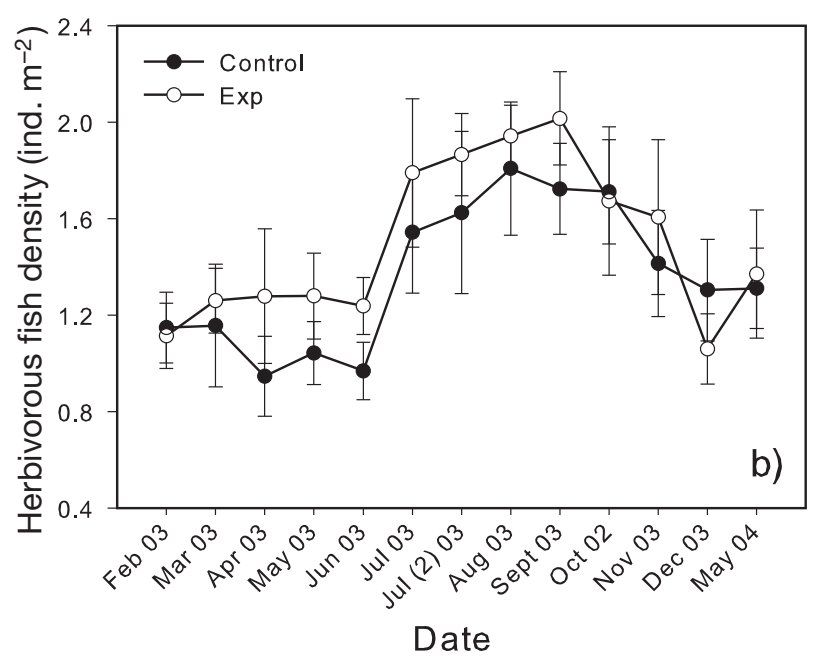

Fig. 3. (a) Total fish density (ind. $\mathrm{m}^{-2}$ ) and (b) density (ind. $\mathrm{m}^{-2}$ ) of herbivorous fishes (pooled densities of Scaridae and Acanthuridae species) over time and treatment. Mean \pm SE. Results of statistical tests are given in Table 3 

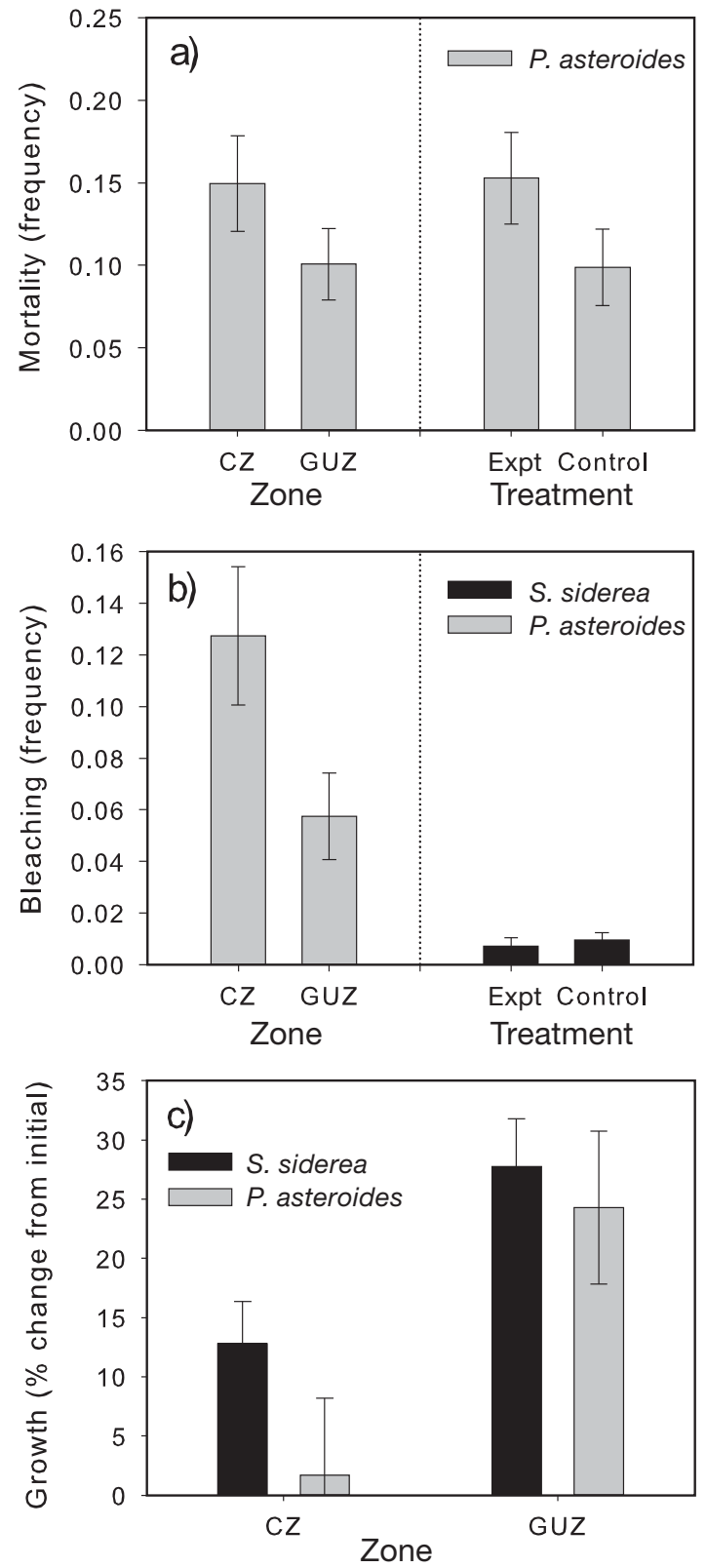

Fig. 4. Porites asteroides and Siderastrea siderea. (a) Mortality, (b) bleaching, and (c) coral growth (all in \%, \pm SE) for the 2 hard coral species, showing only those factors that were statistically significant effects have used either caging experiments, aquariums, or transplanted or placed algae in direct or close contact with corals and generally over short time periods (Jompa \& McCook 2002, 2003, Nugues \& Bak 2006, Smith et al. 2006, Titlyanov et al. 2007, Foster et al. 2008, Liu et al. 2009, Rasher \& Hay 2010). Longterm field experiments have found fewer negative interactions (Venera-Ponton et al. 2011), and often specific to species (Nugues \& Bak 2006) or limited to physical shading or abrasion rather than indirect and lethal interactions (Box \& Mumby 2007).

These above studies generally suggest negative responses of coral to algal contact, but the responses can be very species-specific depending on the corals and algae used in the experiments, and sometimes corals can be unaffected or be competitively dominant to algae (McCook et al. 2001, Nugues \& Bak 2006, Vu et al. 2009). Sometimes the results of shortterm species interactions can be reversed when given more time or with different spatial arrangements (Chornesky 1989, Idjadi \& Karlson 2007) or influenced by environmental conditions such as water quality and herbivory (Nugues \& Roberts 2003, Sotka $\&$ Hay 2009). For example, if coral mesenterial filaments are part of the competitive interaction, it may take some time for corals to grow them and respond to competitors (Lapid \& Chadwick 2006).

The algal taxa on these patch reefs were both very abundant and diverse (McClanahan et al. 2001) and included taxa such as Halimeda, Lobophora, and Dicytota in abundance, which are expected to be competitors, promote diseases, and have allelopathic effects on corals (Nugues et al. 2004, Rasher \& Hay 2010). Interestingly, in this experiment, which did not promote direct contact of coral and algae but rather used natural algal abundances and conditions of water quality and flow typical of lagoonal reef conditions, the negative impacts of these algal species were not observed on transplanted corals. The corals used in the present study were expected to represent 2 of a number of life history types. They did respond differently to the environmental conditions with

Table 4. Mean coral growth (SE in parentheses) for each transplant location on the reef (windward, middle, and leeward) by management zone, irrespective of treatment. Coral growth was calculated as \% change in colony size from initial (January 2003) to final (August 2004) sampling period. Significant 3 -factor ANOVA results (Zone $\times$ Treatment $\times$ Location) for coral growth are shown at right: ${ }^{*} \mathrm{p}<0.05,{ }^{* *} \mathrm{p}<0.01$. Insignificant interactions are not shown

\begin{tabular}{|c|c|c|c|c|c|c|c|c|}
\hline \multirow[t]{2}{*}{ Coral species } & \multicolumn{3}{|c|}{ Conservation zone -} & \multicolumn{3}{|c|}{$\longrightarrow$ General use zone } & \multirow[t]{2}{*}{ Zone } & \multirow{2}{*}{$\begin{array}{l}\text { Location } \times \\
\text { Treatment }\end{array}$} \\
\hline & Windward & Middle & Leeward & Windward & Middle & Leeward & & \\
\hline Porites asteroides & $3.0(6.2)$ & $-1.1(13.2)$ & $3.0(15.5)$ & $33.9(9.6)$ & $25.7(8.2)$ & $13.2(14.9)$ & * & \\
\hline Siderastrea siderea & $17.4(7.2)$ & $9.6(2.2)$ & $11.4(7.8)$ & $23.1(7.1)$ & $20.1(6.3)$ & $40.1(6.0)$ & $* *$ & * \\
\hline
\end{tabular}


Porites asteroides, as expected, being more sensitive than the robust Siderastrea siderea (Muthiga \& Szmant 1987). However, the lack the predictive response to algae for these corals may reflect increased capacity to tolerate declining environmental conditions on Caribbean reefs. Both $P$. asteroides and $S$. siderea are currently common to Caribbean reefs and may even increase in abundance in recent decades (Green et al. 2008, Huntington et al. 2011).

Interestingly and unexpectedly, the experimental removal of macroalgae on the reefs seemed to result in greater incidence of bleaching. This has, however, been reported elsewhere in unpublished observations and literature (Jompa \& McCook 1998) and may be due to lack of shading from macroalgal canopy or lower water quality on control reefs. We did not find any evidence for reduced light on control reefs by our turbidity measure, but there was evidence for a $13 \%$ reduced water flow on the algal reduction treatments. Changing water flow can enhance bleaching if it significantly changes conditions to which the corals have acclimated (McClanahan et al. 2005, van Woesik et al. 2005). Bleaching was expected to represent a response to poor health and possibly disease, but here it is most likely influenced by water flow and changes during the warm season. It is unclear why reducing algae would reduce water flow but perhaps algae create a slightly more turbulent flow that is detected by this clod dissolution method.

Our experimental results have several limitations to generality that can be expected from site-specific large-scale experiments. First, our results are specific to the grazing intensity, reserve efficacy, species selection, habitat, and biogeographic conditions of Glover's Atoll patch reefs and not readily generalized to the larger Caribbean. Hard corals dominated Glover's Atoll in the early 1970s, and hence the shallow, lagoonal abiotic conditions, favored high coral cover (Wallace \& Schafersman 1977) prior to widescale mortality after 1983. The reserve effect was not large in terms of the initial conditions and response to the algal removal, but there was evidence for larger herbivores and somewhat higher herbivory in the fisheries closure. However, possible poaching in reserves and habitat-specific responses of fish to reserve protection may have prevented strong effects of fisheries closure in this manipulation (Huntington et al. 2010, Karnauskas et al. 2011). The reserve was legal for $\sim 8 \mathrm{yr}$, but effective management was delayed by a few years, and this may explain the smaller reserve effect than reported in the oldest Caribbean reserves where reserve protection led to higher numbers of grazing fishes that reduced algal cover and facilitated coral recovery (Mumby et al. 2006, Mumby \& Harborne 2010). Nevertheless, lower water flow in the fisheries closure than in the fished reefs appeared to have a greater influence on the experimental results than macroalgae and fishing, for our conditions and scale of study.

An alternative explanation for the unexpected results is that corallivory is higher in the reserve (Rotjan \& Lewis 2005, 2006) and may have an interactive effect in which the presence of macroalgae deters predation on corals by herbivores (VeneraPonton et al. 2011). Rotjan \& Lewis (2005) report high corallivory of Porites asteroides and this species had the lowest growth rates in the reserve, which is supported by observed higher numbers of stoplight and redband parrotfishes in the CZ versus GUZ. Given that incidence of predation were not quantified in this study, these conclusions remain speculative, but studies in old non-Caribbean reserves have reported that corallivory causes retarded recovery after disturbances (McClanahan et al. 2005). Nonetheless, the patterns observed here and the findings of a recent study (Venera-Ponton et al. 2011) suggest that coralalgal interactions are considerably more complicated and that additional factors are involved than proposed by the common coral-algal competition hypotheses.

A final potential complication of the reserve effect is that we measured a $23 \%$ lower water flow in the CZ than the GUZ that could have confounded the effect of the fisheries closure. Water flow and the placement of the reserve in lower flow environment may explain the higher growth rates of corals outside of the reserve, but this difference was not found between years in a longer-term study of changes in coral cover (McClanahan et al. in press). Water temperature measurement in and out of the fisheries closures revealed slightly lower variation in the GUZ than CZ (6\%) over a 2 yr period, suggesting that the temperature regimes could also have a small effect (McClanahan et al. in press). Large-scale natural experiments are expected to have some natural environmental variation that is difficult to control for and we suggest this variation may be influential but small relative to the very large algal reduction effects in this study.

A second weakness is that our experimental design used healthy-looking, larger colonies of 2 coral species not noted for their losses in recent time. Strong effects of coral-algal competition may be greater on smaller colonies or juvenile colonies (Raymundo \& Maypa 2004, Box \& Mumby 2007, Idjadi et al. 2010, Venera-Ponton et al. 2011). Similar to our results, Vu 
et al. (2009), using small but not juvenile corals, did not detect negative effects of 3 common macroalgal species on coral growth in their short-term study. Furthermore, coral-algal competition may be greater on more susceptible species such as Agaricia agaricites (Nugues \& Bak 2006). Perhaps the lack of a branching coral form in the experiment explains the lack of predicted responses, as branching taxa have been suggested to be most susceptible to competition with algae (Lirman 2001). Nevertheless, the present study does not support the negative indirect effects of algae on the abundant Caribbean species Porites asteroides and Siderastrea siderea.

Thirdly, the algal reduction treatment effect, while implemented consistently across all manipulated patch reef and resulting in very large decreases in algal biomass on treatment reefs, was variable across the atoll, the management zone, and over time. Erect algal biomass on treatment reefs was higher in the CZ than in their GUZ counterparts. Despite equivalent effort to remove algal biomass from all treatment reefs, the treatment effect was not uniform across management zones, but the differences were small compared to the controls but still might have resulted in more favorable conditions for coral growth in the GUZ compared to the CZ. Furthermore, all algal cover quantified at Glover's Atoll, regardless of macroalgal reduction treatment or management zone, was $>20 \%$ for the majority of the study period. Erect algal cover on reduction patches exceeded the mean regional cover of macroalgae reported for the western Caribbean (mean $\pm \mathrm{SE}: 15.3 \pm 0.4 \%$ ) over the same time period (Schutte et al. 2010), attesting to the abnormally high macroalgal cover at Glover's Atoll compared to other field studies in the Caribbean (Nugues \& Bak 2006). The slow increase in algal cover over time in the treatment occurred due to low-lying resilient taxa that did not contribute greatly to biomass but did produce new thalli after one month, which contributed to this cover increase. Indeed, mean cover of erect algae remaining on our reduction treatment patches contrasts with the complete removal of macroalgae achieved in smallerscale experiments and could explain the variable results among investigation (Box \& Mumby 2007, Venera-Ponton et al. 2011). Nevertheless, despite these limits, the considerably higher algal biomass on the control reefs was not sufficient to kill corals over the study period, which suggests that the relatively smaller environmental variation observed within experimental treatments, space, and time were unlikely to greatly influence the conclusions.

\section{Restoration and conservation implications}

The experimental removal of algae failed to clearly improve coral health and reverse the ecological change reported on these reefs (McClanahan \& Muthiga 1998, McClanahan et al. 2001). Various experimental manipulations, such as removing algae, adding the sea urchin Diadema antillarum, and fisheries management have failed to return these patch reefs to coral dominance (McClanahan et al. 2001). Adding sea urchins can assist in reducing algae, but they can also quickly decline within days after additions (Maciá et al. 2007, T. R. McClanahan pers. obs.). Removing algae by one-time pulses resulted in the return of algae before corals could recruit or grow (McClanahan et al. 2001), and closing the area to fishing for $>15$ yr did not decrease algae and increase coral cover (McClanahan et al. in press). Here, we removed algae monthly for over $1 \mathrm{yr}$, but there was no indication of a return in coral cover or improved conditions for transplanted corals. The sea urchin, D. antillarum, has been present in this reef for many millennia, but their body part numbers in sediments have shown large fluctuations that suggest they are not a continuous influence on these reefs (Gischler 2010) and still remain entirely absent from the majority of patch reefs within the lagoon (McClanahan 1999),

The outlook for easily and quickly reversing the observed ecological change through a return of environmental and herbivore conditions are not hopeful on the scale of the studies undertaken to date. It is possible that by manipulating multiple factors simultaneously, such as combining manual reductions in macroalgal abundances with grazer additions (i.e. Diadema antillarium transplants) to increase grazing pressure, will work better to increase coral cover. The costs are, however, likely to be considerable and not practical on the scale of this problem. An alternative and low-cost method may be to ban fishing of herbivores on large scales, such that fisheries closures are not the only means to restore their populations, yet this method is untested. Additionally, informed placement of fisheries closures into habitats and environments known to respond favorably to reserve protection is expected to increase their efficacy in enhancing recovery of herbivores and corals (Huntington et al. 2010, McClanahan \& Karnauskas 2011). From these results, manual and continuous removal of algae does not appear to be a viable management strategy to restore degraded reefs unless this activity persists over many years or is undertaken in well-enforced fisheries reserves where grazing intensities have increased. 
Acknowledgements. This is publication no. 36 of the Middle Cay Research Station. Research was supported by the Wildlife Conservation Society and clearance provided by the Belizean Fisheries Department. D. Westby's help with the logistics is greatly appreciated.

\section{LITERATURE CITED}

Alvarez-Filip L, Dulvy NK, Gill JA, Côté IM, Watkinson AR (2009) Flattening of Caribbean coral reefs: region-wide declines in architectural complexity. Proc Biol Sci 276: 3019-3025

Anzai R (2001) The effects of coral morphology and water flow rates on coral growth and passive diffusion. MSc thesis, University of Ryukyus

> Aronson RB, Precht WF (2001) White-band disease and the changing face of Caribbean coral reefs. Hydrobiol 460: 25-38

> Box SJ, Mumby PJ (2007) Effect of macroalgal competition on growth and survival of juvenile Caribbean corals. Mar Ecol Prog Ser 342:139-149

> Carpenter RC, Edmunds PJ (2006) Local and regional scale recovery of Diadema promotes recruitment of scleractinian corals. Ecol Lett 9:271-280

Chornesky EA (1989) Repeated reversals during spatial competition between corals. Ecology 70:843-855

> Diaz-Pulido G, Harii S, McCook LJ, Hoegh-Guldberg O (2010) The impact of benthic algae on the settlement of a reef-building coral. Coral Reefs 29:203-208

> Doty MS (1971) Measurement of water movement in reference to benthic algal growth. Bot Mar 14:32-35

> Foster NL, Box SJ, Mumby PJ (2008) Competitive effects of macroalgae on the fecundity of the reef-building coral Montastraea annularis. Mar Ecol Prog Ser 367: 143-152

Gardner TA, Cote IM, Gill JA, Grant A, Watkinson AR (2003) Long-term region-wide declines in Caribbean corals. Science 301:958-960

> Gischler E (2010) Possible fossil echinoid mass mortality detected in holocene lagoons, Belize. Palaios 25:260-268

Green DH, Edmunds PJ, Carpenter RC (2008) Increasing relative abundance of Porites astreoides on Caribbean reefs mediated by an overall decline in coral cover. Mar Ecol Prog Ser 359:1-10

> Hay ME (1981) Spatial patterns of grazing intensity on a Caribbean barrier reef: herbivory and algal distribution. Aquat Bot 11:97-109

Hay ME, Colburn T, Downing D (1983) Spatial and temporal patterns in herbivory on a Caribbean fringing reef: the effects on plant distribution. Oecologia 58:299-308

Hughes TP (1994) Catastrophes, phase shifts, and largescale degradation of a Caribbean coral reef. Science 265: 1547-1551

Hughes TP, Graham NAJ, Jackson JBC, Mumby PJ, Steneck RS (2010) Rising to the challenge of sustaining coral reef resilience. Trends Ecol Evol 25:633-642

Huntington BE, Karnauskas M, Babcock E, Lirman D (2010) Untangling natural seascape variation from marine reserve effects using a landscape approach. PLoS ONE 5: e12327

Huntington BE, Karnauskas M, Lirman D (2011) Corals fail to recover at a Caribbean marine reserve despite ten years of reserve designation. Coral Reefs (in press) doi: 10.1007/s00338-011-0809-4
Idjadi JA, Karlson RH (2007) Spatial arrangement of competitors influences coexistence of reef-building corals. Ecology 88:2449-2454

Idjadi JA, Haring RN, Precht WF (2010) Recovery of the sea urchin Diadema antillarum promotes scleractinian coral growth and survivorship on shallow Jamaican reefs. Mar Ecol Prog Ser 403:91-100

Jompa J, McCook LJ (1998) Seaweeds save the reefs?!: Sargassum canopy decreases coral bleaching on inshore reefs. Reef Res 8:5

Jompa J, McCook LJ (2002) The effects of nutrients and herbivory on competition between a hard coral (Porites cylindrica) and a brown alga (Lobophora variegata). Limnol Oceanogr 47:527-534

> Jompa J, McCook LJ (2003) Coral-algal competition: macroalgae with different properties have different effects on corals. Mar Ecol Prog Ser 258:87-95

Karnauskas M, Huntington BE, Babcock E, Lirman D (2011) Preexisting spatial patterns in fish abundance influence whether a Caribbean marine reserve increases or decreases fishing mortality. Mar Ecol Prog Ser 432: 235-246

Kline DI, Kuntz NM, Breitbart M, Knowlton N, Rohwer F (2006) Role of elevated organic carbon levels and microbial activity in coral mortality. Mar Ecol Prog Ser 314: 119-125

> Kuffner IB, Walters LJ, Becerro MA, Paul VJ, RitsonWilliams R, Beach KS (2006) Inhibition of coral recruitment by macroalgae and cyanobacteria. Mar Ecol Prog Ser 323:107-117

Kuntz NM, Kline DI, Sandin SA, Rohwer F (2005) Pathologies and mortality rates caused by organic carbon and nutrient stressors in three Caribbean coral species. Mar Ecol Prog Ser 294:173-180

> Lapid ED, Chadwick NE (2006) Long-term effects of competition on coral growth and sweeper tentacle development. Mar Ecol Prog Ser 313:115-123

Lessios HA (1988) Mass mortality of Diadema antillarum in the Caribbean: what have we learned? Annu Rev Ecol Syst 19:371-393

Lirman D (2001) Competition between macroalgae and corals: effects of herbivore exclusion and increased algal biomass on coral survivorship and growth. Coral Reefs 19:392-399

> Lirman D, Orlando B, Maciá S, Manzello D, Kaufman L, Biber P, Jones T (2003) Coral communities of Biscayne Bay, Florida and adjacent offshore areas: diversity, abundance, distribution, and environmental correlates. Aquat Conserv Mar Freshwat Ecosyst 13:121-135

Liu PJ, Lin SM, Fan TY, Meng PJ, Shao KT, Lin HJ (2009) Rates of overgrowth by macroalgae and attack by sea anemones are greater for live coral than dead coral under conditions of nutrient enrichment. Limnol Oceanogr 54:1167-1175

> Maciá S, Robinson MP, Nalevanko A (2007) Experimental dispersal of recovering Diadema antillarum increases grazing intensity and reduces macroalgal abundance on a coral reef. Mar Ecol Prog Ser 348:173-182

McClanahan TR (1999) Predation and the control of the sea urchin Echinometra viridis and fleshy algae in the patch reefs of Glovers Reef, Belize. Ecosystems 2:511-523

McClanahan TR, Karnauskas M (2011) Benthic cover, current strength, herbivores and their distribution and interrelationships in the patch reefs of Glover Reef Atoll, Belize. Coral Reefs 30:9-19 
McClanahan TR, Muthiga NA (1998) An ecological shift in a remote coral atoll of Belize over 25 years. Environ Conserv 25:122-130

McClanahan TR, Nugues M, Mwachireya S (1994) Fish and sea urchin herbivory and competition in Kenyan coral reef lagoons: the role of reef management. J Exp Mar Biol Ecol 184:237-254

- McClanahan TR, McField M, Huitric M, Bergman K and others (2001) Responses of algae, corals and fish to the reduction of macroalgae in fished and unfished patch reefs of Glovers Reef Atoll, Belize. Coral Reefs 19:367-379

McClanahan TR, Baker AC, Ateweberhan M, Maina J, Moothien-Pillay KR (2005) Refining coral bleaching experiments and models through reiterative field studies. Mar Ecol Prog Ser 305:301-303

McClanahan TR, Muthiga NA, Coleman RA (in press) Testing for top-down control: can post-disturbance fisheries closures reverse algal dominance? Aquat Conserv Mar Freshw Ecosyst

> McCook LJ, Jompa J, Diaz-Pulido G (2001) Competition between corals and algae on coral reefs: a review of evidence and mechanisms. Coral Reefs 19:400-417

Mumby PJ, Harborne AR (2010) Marine reserves enhance the recovery of corals on Caribbean reefs. PLoS ONE 5: e8657

Mumby PJ, Dahlgren CP, Harborne AR, Kappel CV and others (2006) Fishing, trophic cascades, and the process of grazing on coral reefs. Science 311:98-101

Muthiga NA, Szmant AM (1987) The effects of salinity stress on the rates of aerobic respiration and photosynthesis in the hermatypic coral Siderastrea siderea. Biol Bull 173: 539

> Nugues MM, Bak RPM (2006) Differential competitive abilities between Caribbean coral species and a brown alga: a year of experiments and a long-term perspective. Mar Ecol Prog Ser 315:75-86

Nugues MM, Roberts CM (2003) Coral mortality and interaction with algae in relation to sedimentation. Coral Reefs 22:507-516

> Nugues MM, Delvoye L, Bak RPM (2004) Coral defense against macroalgae: differential effects of mesenterial filaments on the green alga Halimeda opuntia. Mar Ecol Prog Ser 278:103-114

Paddack MJ, Reynolds JD, Aguilar C, Appeldoorn RS and others (2009) Recent region-wide declines in Caribbean reef fish abundance. Curr Biol 19:590-595

Rasher DB, Hay ME (2010) Chemically rich seaweeds poison

Editorial responsibility: Janet Ley,

St. Petersburg, Florida, USA corals when not controlled by herbivores. Proc Natl Acad Sci USA 107:9683-9688

Raymundo LJ, Maypa AP (2004) Getting bigger faster: mediation of size-specific mortality via fusion in juvenile coral transplants. Ecol Appl 14:281-295

River GF, Edmunds PJ (2001) Mechanisms of interaction between macroalgae and scleractinians on a coral reef in Jamaica. J Exp Mar Biol Ecol 261:159-172

Rotjan RD, Lewis SM (2005) Selective predation by parrotfishes on the reef coral Porites astreoides. Mar Ecol Prog Ser 305:193-201

Rotjan RD, Lewis SM (2006) Parrotfish abundance and selective corallivory on a Belizean coral reef. J Exp Mar Biol Ecol 335:292-301

> Schutte VGW, Selig ER, Bruno JF (2010) Regional spatiotemporal trends in Caribbean coral reef benthic communities. Mar Ecol Prog Ser 402:115-122

Selig ER, Bruno JF (2010) A global analysis of the effectiveness of marine protected areas in preventing coral loss. PLoS ONE 5:e9278

Smith JE, Shaw M, Edwards RA, Obura D and others (2006) Indirect effects of algae on coral: algae-mediated, microbe-induced coral mortality. Ecol Lett 9:835-845

Sotka EE, Hay ME (2009) Effects of herbivores, nutrient enrichment, and their interactions on macroalgal proliferation and coral growth. Coral Reefs 28:555-568

> Thompson TL, Glenn EP (1994) Plaster standards to measure water motion. Limnol Oceanogr 39:1768-1779

van Woesik R, Nakamura T, Yamasaki H, Sheppard C (2005) Comment on 'Effects of geography, taxa, water flow, and temperature variation on coral bleaching intensity in Mauritius' (McClanahan et al. 2005). Mar Ecol Prog Ser 305:297-299

Venera-Ponton DE, Diaz-Pulido G, McCook LJ, RangelCampo A (2011) Macroalgae reduce growth of juvenile corals but protect them from parrotfish damage. Mar Ecol Prog Ser 421:109-115

> Vu I, Smelick G, Harris S, Lee SC, Weil E, Whitehead RF, Bruno JF (2009) Macroalgae has no effect on the severity and dynamics of Caribbean yellow band disease. PLoS ONE 4:4514-4520

Wallace RJ, Schafersman SD (1977) Patch reef ecology and sedimentology of Glovers Reef Atoll, Belizean. In: Frost SH, Weiss MP, Saunders JB (eds) Reefs and related carbonates - ecology and sedimentology. Studies in Geology. The American Association of Petroleum Geologists, Tulsa, OK, p 37-52

Submitted: February 10, 2011; Accepted: July 7, 2011 Proofs received from author(s): September 1, 2011 